\title{
Rhetoric of a troubled industry: The case of the Dundee jute industry during the inter-war period
}

\begin{abstract}
This study examines the rhetorical strategies deployed by supporters of the Dundee jute industry during the legislative debate surrounding British trade policy of the inter-war period. It conducts a content analysis of the February 2, 1938 House of Commons debate on a motion entitled 'Importations from Overseas'. This debate highlights the position and the rhetorical strategies of the jute industry through its parliamentary surrogates. Analysis suggests that rhetorical strategies challenged policy, while avoiding a direct or explicit challenge to the dominant institutional logic of free trade. This study also furthers our understanding of government-industry relations in the jute industry during the inter-war period.
\end{abstract}

Keywords: rhetoric, protectionism, free trade, institutional logics, legitimacy, international competition, trade policy, Dundee jute industry 


\section{Introduction}

An important aspect of changing public attitudes and shifting government policy is the successful deployment of rhetorical strategies. Attention has been given to this phenomenon in the academic literature concerned with the use of rhetoric to legitimize shifts in institutional logics resulting in profound institutional change. Suddaby and Greenwood (2005) argue that "[r]hetoric, and particularly the 'new rhetoric' (Freedman and Medway, 1994), restricts its focus to explicitly political or interest-laden discourse and seeks to identify genres or recurrent patterns of interests, goals, and shared assumptions that become embedded in persuasive texts ..." (p. 40). The interestladen discourse of this study is the public discourse employed by the Dundee Jute Industry (DJI) to lobby for increased protectionism against foreign competition.

In examining the connection between rhetoric and legitimacy, it will become clear that the extant literature coalesces around three important themes: the theoretical and practical implications of rhetoric, the need for rhetorical appeals to shift institutional logics, thus legitimating a new organisational, or institutional, order, and the link between rhetoric (and legitimacy) to rationality and narrative.

The traditional, primary division in the organization studies scholarship has been between those who emphasize institutional sources of legitimacy (e.g., DiMaggio \& Powell, 1983; Meyer \& Rowan, 1991; Meyer \& Scott, 1983a) and those who focus on strategic sources of legitimacy (e.g., Ashforth \& Gibbs, 1990; Dowling \& Pfeffer, 1975; Pfeffer, 1981). However, more recently, there has been a growing body of literature which explores language as a third possible source of legitimacy. (e.g., Heracleous and Hendry (2000); Philips and Hardy (2002); Philips, et al. (2004) and Golant and Sillince, (2007)).

Emerging from the literature of this language-focused approach, a number of scholars have identified rhetoric as a central legitimating device employed in the re-shaping of institutional logics through these contests of legitimacy. This small, but growing, body of literature examines the ways in which rhetoric is used to build legitimacy (Suddaby and Greenwood 2005; Vaara, et al. 2006; Van Leeuwen 2007; Vaara and Tienari 2008; Erkama and Vaara 2010).

Suddaby and Greenwood (2005) examine the role that rhetoric played in the legitimation of significant shifts in the institutional order of multi-disciplinary professional firms (MDP). This 'legitimacy contest' was precipitated by the purchase of a law firm by one of the Big Five accounting firms. This acquisition sparked debate as to whether it was appropriate to allow the comingling of legal and auditing services within a single organisation. The authors employ neoinstitutional theory to answer how affected actors seek to confer or deny legitimacy to new institutional forms. They note that new institutional forms do not emerge frequently. Further, they assert that it is only through the displacement of the existing institutional logics, with an amended and supporting set of logics, that new institutional forms acquire legitimacy and come into existence. They argue that this displacement of logics is achieved primarily through the use of persuasive language or rhetoric (p. 35). To examine the shift in institutional logics of MDPs, they took as their primary data the transcripts of testimony given to the American Bar Association (ABA) Commission to Study Multidisciplinary Practice and the Securities and Exchange Commission (SEC) Public Hearings on Auditor Independence. "Collectively the transcripts and supporting documents provide[d] a comprehensive account of the language used to contest the legitimacy of the new organizational form. ... The data thus capture the arguments used by key actors engaged in a legitimacy contest over institutional logics" (Suddaby and Greenwood 2005: 42). From this analysis, five categories of classification emerged: historical, value-based, 
teleological, ontological and cosmological. This work contributes to the understanding of the development of cognitive legitimacy by illustrating how rhetoric is used to shape institutional logics thus creating momentum for, and eliminating resistance to, institutional change.

Like Suddaby and Greenwood (2005), Erkama and Vaara (2010) are concerned with rhetorical strategies of legitimation. Specifically, they focus on the rhetorical legitimation of the closure of the Volvo-owned, Carrus manufacturing plant in Finland. The authors compiled a dataset in line with a 'classical qualitative case study' in which they examined transcripts of interviews, media reports, minutes of meetings, confidential company documents as well as official publications, through the use of an 'abductive' approach that allowed them to refine their theoretical ideas as their analysis progressed. The aim of their research was to provide a "more nuanced understanding of how contemporary industrial closures are legitimated and resisted ... [and] ... increase the theoretical understanding of the role of rhetoric in legitimation more generally" (p. 813). The authors draw on the same classic rhetorical classification system as Suddaby and Greenwood (2005), that of logos, pathos and ethos, but add the categories of autopoiesis and cosmos. They assert that this allows a better understanding of "the multiple discursive facets in the legitimation of drastic organizational restructuring decisions such as industrial shutdowns" (p. 833).

Vaara, et al (2006) also examine the phenomenon of organizational transformation. Whereas, Suddaby and Greenwood examined the legitimation process that allowed the amalgamation of legal and audit services in MDP firms, Vaara, et al examined the discursive legitimation of industrial restructuring. The authors explored the merger between the Finnish pulp and paper firm Enso with the Swedish firm Stora. Using Critical Discourse Analysis as their method, which was based both on the work of Fairclough $(1997 ; 2003)$ and the discourse historical method of Wodak, et al. (1999) and Wodak and Meyer (2002), the authors examine the media accounts of the merger process exclusively (p. 6-7). Their research takes the form of a three-stage analysis. In the first stage, they conduct a thematic analysis in order to highlight important issues within the case and in the arena of global industrial restructuring more broadly. The second stage of analysis involved an interdiscursive analysis, with attention to discourses employed when addressing the previously identified themes. They were able to identify neoliberal, nationalistic, humanistic and entertainment discourses. Finally, they employed a textual analysis in order to discover how particular discourses were employed for either legitimation or de-legitimation purposes. The result was the identification of five main types of legitimation strategies: normalization, authorization, rationalization, moralization and narrativization. The most important contributions, relevant to legitimating of organizational change, made by the authors are two-fold. Importantly, they contribute to the understanding of discursive elements of legitimacy through the creation of a model of legitimation strategies. While perhaps not revolutionary, in that rationalisation and moralisation match the classic rhetorical categories of logos and ethos closely and their categories of normalisation and authorisation could comfortably be associated with Weberian concepts of traditional and legal domination, this framework is a useful synthesis of rhetorical strategies of legitimation in the context of changes to industrial institutional frameworks.

As is clear from this recent body of literature on the rhetorical sources of legitimacy, scholars have formulated their own frameworks to account for the ways in which rhetorical strategies are deployed in legitimation processes. While a general consensus on a universal system of categorisation has not been reached, significant overlap in the categories, if not the nomenclature, is evident. The contribution of this body of literature is central to informing both the theory and the method of this research project. 
In this study, we have examined the deliberate use of persuasive language deployed in the UK House of Commons during the 1938 parliamentary debate concerning the possibility of trade regulation and the future of the Dundee Jute Industry (DJI). This debate was a reflection of the industry's attempt to resist the dominant institutional logics of free trade and shift UK trade policy on to a more protectionist footing. As explored above, the extant literature is focused on analyzing the use of language for the purpose of altering perceptions of legitimacy and shifting dominant logics. We anchor this study of the use of rhetoric in an institutional legitimation contest in the empirical context of the DJI during the inter-war period. In doing so, we accept the assertion of Erkama and Vaara (2010) that there is a need for future research of "cases in different sociopolitical and cultural contexts to be able to distinguish and compare rhetorical dynamics in more nuanced ways" (p. 835). Therefore, this paper asks the following question: What rhetorical strategies were deployed by, and on behalf of, the Dundee Jute industry during the public policy debate surrounding British trade policy during the inter-war period?

\section{The Dundee Jute Industry}

The textile sector in Dundee began with the prosperous flax spinning and weaving industry in the late 18th century. However, the Crimean war in 1854 brought an abrupt halt in the import of flax, leading to a sudden rise in the price of goods. Under these circumstances, manufacturers were forced to introduce jute (Gauldie 1969). The initial resistance from customers about jute's inferior quality was soon overcome when its cost advantage over flax became apparent (Woodhouse and Brand 1934) and jute soon replaced flax as the industry's staple fibre.

By the 1860s, the DJI experienced rapid growth. However, by the 1880s, continental tariffs and competition from Calcutta in India were cutting into Dundee's traditional markets (Lenman, Lythe and Gauldie 1969: 33). As the DJI was dependent heavily on export markets, this competition had serious implications. The industry, through the Dundee Chamber of Commerce (DCC), made numerous representations to the Board of Trade (BoT) in an attempt to negotiate more favourable

rates. Even so, this had little effect and the tariffs continued into the 1880s. By 1883, import tariffs had been imposed in all major markets across Europe on jute goods. The damaging impact on the industry can be adjudged by the great amount of time devoted to resolving this issue in the DCC. By the end of the nineteenth century there was a sense of acceptance that prohibitive import tariffs were part of business life.

To compound its plight, the industry was facing another, and more serious, competitive threat from India. By the 1890 s the Indian industry had expanded rapidly. In 1882, it had 21 mills, with a total of 5655 looms and 91,000 spindles, which by 1892 increased to 26 with 8101 looms and 162,000 spindles. However, when global demand fell in the 1920s, the Indian industry was unable to reduce its production (Stewart 1998: 93). Attempts were made by the Indian Jute Manufacturers Association to cut output and restrictions were enforced in the form of a curtailment of working hours up to 40 hours a week (Gupta 2005: 539). However, not all firms joined the agreement and these 'outside' firms continued to operate at 60 hours per week. Many of the 'outside' firms were newly-established with Indian ownership. With relatively new machinery, it was in their interest to increase output to recover their investments (Gupta 2005: 539).

For Dundee, such growing international competition led to increased pressure in all areas, including yarn, cloth, sacks and bags. Imports into the domestic market rose sharply e.g., piece goods (any fabric that has been made-up for sale) rose from 564.33 in 1924 to 714.63 (000 square yards) in 1935. Similarly, the import of sacks and bags rose from 428 in 1924 to 639 (000 dozens) in 1936. In addition to competition in their domestic market, the Dundee firms faced restrictions in major 
export markets in continental Europe. This was driven by high import taxes imposed on the continent to protect domestic industries. For example, in 1929-30 the import tax in France was $64 \%$, Germany $50 \%$, Belgium $38 \%$ and Italy $30 \%$ respectively ${ }^{1}$. As a consequence, the DJI underwent a significant contraction. While production increased in India by $48.5 \%$ and Continental Europe by $21 \%$, it decreased in Dundee by $35 \%{ }^{2}$. The industry responded by making nominal reductions in wages in 1930 and 1931 to regain some competitiveness (Morelli and Tomlinson 2008). Yet, such measures did not go far enough to regain the industry's competitiveness in the global market.

It was within this context that the DJI, particularly the manufacturers (spinners and weavers), through the Association of Jute Spinners and Manufacturers (AJSM), attempted to influence government policy through the deployment of rhetorical strategies intended to shift the dominant free-trading logics to a more favourable protectionist policy logic. With a greater understanding of the rhetorical strategies employed by industry proponents during this key Parliamentary debate, we will explore the relevance of Vaara et al's (2006) model for linguistic-based legitimation strategies to our findings.

\section{Method}

This study employs a computer assisted content analysis of the February 2, 1938 House of Commons debate on a motion entitled 'Importations from Overseas'. This debate highlights the position and the rhetorical strategies of the DJI through its parliamentary surrogates. This motion, and subsequent debate, sought to preserve existing tariffs and introduce additional trade protections in an attempt to mitigate the impact of less expensive Indian jute imports on Dundee jute producers within the domestic UK marketplace. While the pro-Jute coalition in the House included specific language around the protection of the DJI, the broader rhetorical debate sought to include the plight of other industries which faced strong competition from competing imports. This was consistent with the general industry strategy of seeking a broad coalition of UK producers, across industries, who faced less expensive competition from foreign goods.

The resultant debate lasted approximately three hours and forty-five minutes and is preserved in the form of a 26,000 word transcription contained in the British parliamentary record, Hansard. This written transcript, available in Hansard, provided the textual dataset for this research project.

\section{Findings}

The debate was initiated by a motion recommending that the Government take a protectionist approach in their negotiations with Dominion and foreign governments. On February 2nd, 1938, in the House of Commons, Sir Arnold Wilson (Member for Hitchin) and Miss Horsbrugh (Member for the City of Dundee) proposed and seconded, respectively, a Private Member's motion entitled 'Importations from Overseas'.

Sir Arnold Wilson's 'Importations from Overseas' motion, that generates this debate, is as follows:

That this House is of opinion that in negotiations for trade agreements with the Dominions and with foreign countries His Majesty's Government, while doing everything possible to

\footnotetext{
${ }^{1}$ Dundee University Archives MS/84/1-64: Dundee Jute Spinners and Manufacturers Association Annual Reports, 1930

${ }^{2}$ Dundee University Archives MS/84/1-64: Dundee Jute Spinners and Manufacturers Association, Annual Report, 1934
} 
assist the export trade and promote the prosperity of the country as a whole, should have special regard to the effect upon particular industries in this country of imports from countries with low standards of wages, especially where the industries in question are concentrated in a limited area in the United Kingdom; and urges that the need for safeguarding the United Kingdom jute industry against the competition of Indian jute goods should be placed in the forefront of the resumed negotiations with the Government of India.

(Hansard: 1938, Vol. 331)

The proponents of this legislation sought the 'safeguard' of tariff barriers on goods from the Dominions and an assurance from the Government that existing tariffs on goods from foreign nations would remain in place. While the debate was primarily intended to focus on, and support the interests of, the DJI, the debate was cast in broad terms, as summarised by Mr Euan Wallace:

"There are, as has been said, two aspects of the Motion on the Paper: first of all, the large general question of imports from low-wage standard countries in relation to trade agreements; and, secondly, the particular subject of the competition of Indian jute goods with the products of Dundee " (Hansard: 1938).

Included in this debate is the introduction of an amendment which proposed a more extreme solution, which was not supported by either Miss Horsbrugh or Sir Arnold. Rather than focusing on the protection of domestic industries, Mr MacLean Wilson, a staunch pro-protectionist Member of Parliament and a former trade unionist, sought a complete ban on all imports from nations that had wage levels and working conditions below those of Great Britain. He articulated his position, as follows:

"[...] taking note of the effects of the exploitation in the jute industry in Bengal by British and other capital, calls upon the Government to promote an international conference for the purpose of fixing minimum standards of labour conditions and imposing an international prohibition of imports of goods produced under conditions below those standards so long as there is an alternative source of supply of such goods produced under fair and reasonable conditions" (Hansard: 1938).

While this severe policy could have assisted the DJI with its concerns of the inexpensive Indian imports of jute, Sir Arnold and Miss Horsbrugh considered the motion too extreme and a risk to their, more modest, proposal contained in the original motion. Generally, there was little popular support for such drastic action and Mr Wilson appeared to have a primarily ideological motivation, given his trade unionist background, beyond the support of any one industry in general or the DJI in particular.

In fact Mr Wilson noted, he had little sympathy for the DJI, especially the owners of the firms:

"[...] a, great deal of capital sunk in the Bengal jute industry was British capital - Dundee capital. It was British capital that set up the mills in Bombay and in India generally. That is where the trouble began and how it began. Not only was there British capital but there was British machinery, and there were managers from Dundee, technicians from Dundee, workers from Dundee, teaching Indians how to operate these jute machines. That was the beginning of the trouble" (Hansard: 1938). 
The proponents of the original motion considered Mr Wilson's amendment unhelpful and a tactic of delay. Miss Horsbrugh stated her opposition to the amendment:

"I think I made it clear that I oppose [the amendment] because I consider that it is a delaying Amendment, and that while you are trying to get up the standard of the people in India and elsewhere and trying to get an agreement through the International Labour Office, the standard of the people of this country and of Dundee in particular will go down. My motion is quicker and more likely to succeed" (Hansard: 1938).

These themes of urgency and the protection of the standard of living of British workers figure prominently in the rhetorical strategies of industry proponents. A full accounting of the rhetorical strategies employed by proponents of the industry in an attempt to shift the dominant logics from free trade to protectionism are explored in the following section.

\subsection{Rhetorical Strategies}

In speaking in favor of the Motion, proponents focused their argumentation on mainly two dozen topics. Through further analysis, it was clear that these topics could be grouped into rhetorical themes. There were four rhetorical groupings of argumentation for the proponents of the legislation:

1) Fairness: as a universal good, as it applies in the context of trade and trade policy.

2) Workers' Interests: as an appeal to compassion.

3) National Interest: as an appeal to unity and patriotism.

4) Temporal Arguments: an appeal to urgency which underpinned the first three themes.

These categories illustrate the primary rhetorical strategies intended to legitimate a shift in institutional logics to a more protectionist orientation.

\subsubsection{Fairness}

This theme was revisited numerous times during the debate, as parliamentarians appealed to a sense of fairness in the context of trade. Less expensive imports, produced in jurisdictions in which the cost of production, including labour, was below that of the United Kingdom was deemed to be unfair competition. It was the role of the Government, proponents argued, to reduce or eliminate this source of unfairness through the imposition of tariffs and non-tariff barriers. While the industry proponents asserted that they had no problem with competition and only wanted a fair chance to compete with these foreign goods, there was a suggestion that current free-trading policies were not in reality the result of a truly free market, as foreign producers were not competing fairly.

Proponents employed this strategy not to directly oppose free trade, but to suggest that the current system was inherently unfair and therefore less free market oriented than a situation in which the Government increased tariff barriers, and as a result, fairness by leveling the playing field.

This indirect rhetorical attack on free-trading can be seen in the words of Miss Horsbrugh when she states that she "... want[s] to see tariffs as high as is necessary to equalise the difference between our own standard of living and that of potential importers, but not so high as to exclude a fair element of competition" (Hansard: 1938).

This rhetorical strategy accomplished two goals: First, proponents argued that through a more protectionist approach to UK industry, the Government could assist in the restoration of fairness, 
allowing UK industry to compete with products from lower-cost-of-production jurisdictions. The implication of this argument was that the industry's inability to compete was the result of some undefined unfairness. This attempts to draw the argument away from the dichotomy of protectionism versus free trade, as during this time in UK history protectionists appeared to be losing this policy debate, and rather focus the argument on something universally disliked which was unfair practices. Second, it allowed an indirect attack on current policy, low levels of protection against cheaper imports, by focusing on fair competition, thus leveraging, and co-opting, a foundational principle of the dominant institutional logic of free-trade.

\subsubsection{Compassion}

The second rhetorical theme employed by the industry proponents was that of compassion. Ironically, it was the representatives of the mill and factory owners who advocated vociferously on behalf of workers' rights in this particular context, while resisting pressure to increase wages, improve working conditions and reduce working hours in all normal labour relations contexts.

Attempting to broaden the appeal of their protectionist position, the proponents emphasised the relationship between the overall health of the industry and the resultant benefits to the workers. Continuing to allow low-cost, foreign imports not only encouraged the exploitation of lower-wage workers outside the UK, but it endangered the jobs, standard of living and community livelihood for the many Britons dependent on the Jute industry. Speaking for the proponents of the legislation, Miss Horsbrugh stated:

"I should have liked to have asked the right hon. Gentleman, who has represented the citizens of Dundee, whether he thinks that it is right that while he endeavours to raise the standard of living of people in other parts of the world we should stand by and wait while the standard of living and of employment of the people in this country go down" (Hansard: 1938)?

The rhetorical dilemma presented in this context was one in which inaction on behalf of the Government would force the industry to revert to worse conditions and lower wages for UK workers in order to compete with foreign imports.

Again, proponents employ rhetorical strategies which frame the debate in such a way as to avoid direct conflict with dominant institutional logics. Two overlapping logics involved with this aspect of the debate, as can be seen in the quotation above, are the protection of workers' standards of living and the articulation of a dichotomous, zero-sum game in which the livelihood of British workers is compared with, and set against, the well-being of the foreign worker. While we will explore the underlying logic of national interest below, the logic of Government protection of its citizens'/workers' welfare is embraced through this rhetorical strategy.

\subsubsection{National Interest}

The third rhetorical theme used by industry proponents was one of patriotism and national interest. Again, attempting to frame the debate in the broadest terms possible, and claim as many allies outside the Jute industry as possible, proponents expanded their rhetoric from the welfare of the worker and support of the industry to the benefits to all subjects/citizens and the benefit to the nation. They employed repeatedly rhetoric of unity and national interest. There was a recurrent mention of the 'Made in Britain' ideal and the proponents linked their preferred position on trade 
policy with the health of the British economy and the 'rightful' position of the UK as the centre of a global empire.

This jingoistic approach can be seen in rhetoric promoting the attributes of Britain: "These are great assets. No country in the world has better soil, better mines, no people has a higher character or greater skill” (Hansard, Sir Wilson: 1938).

Also, they sought to emphasize the importance and centrality of the Jute industry to the wellbeing of the national economy.

"This trade is vital to the country. We must never forget what part the jute trade must play in our defences in time of war, and a trade which is vital to the interests of this country cannot be allowed to go down. Nor can an area be allowed to become derelict, and men and women be deprived of their means of livelihood, for the want of a small measure of protection" (Hansard, Miss Horsbrugh: 1938).

Given the recent experience of the Great War, the industry attempted to link its relevance as central to the war effort. Using the rhetoric of national interest, proponents warned the Government against allowing trade policy that would endanger vital industrial capabilities. Yet again, proponents took an indirect approach in challenging the dominant logic of free trade. Even though this rhetorical strategy does more directly challenge this dominant logic, it avoids a direct refutation of free trade and attempts to leverage the strength of the national interest logic, allowing it to compete with the free-trade logic. It is not that protectionism is good and that free-trade is bad, it is that, given the nation's unique needs and particular circumstances, the preferred protectionist policy is necessary and of vital national interest.

\subsubsection{Urgency}

The final rhetorical strategy identified within the argumentation of the industry proponents was one of timing rather than content. Proponents attempted to develop a sense of urgency, which encompassed and supported the other aspects of their rhetoric. Complimentary with the other rhetorical themes, this sense of urgency was repeated to support the need for the Government to act. Relating to the immediate need to act to protect workers, Miss Horsbrugh stated: "I can assure him that my gratitude will be echoed by many people outside this House who fear that their employment is in danger and that trouble is ahead for them unless the Government realise the difficulty and act quickly" (Hansard: 1938).

While this references the need to act quickly to save jobs, a theme of urgency permeates the rhetoric of the debate and is central to the proponents' attempts to pass this legislation. This emphasis on the need to take action, whether real or manufactured, was pronounced: If the future of the DJI is to be secured, action needs to be taken quickly.

Themes of fairness in trade policy, compassion for the impact on British workers, centrality to the national interest and the health of the country and, finally, underpinning these rhetorical strategies with the temporal theme of urgency, were employed by industry proponents and supporters of the 'Importations from Overseas' parliamentary debate.

\section{Discussion}


Proponents of the industry focused on four primary rhetorical strategies in their attempt to pass protectionist-oriented legislation that would protect the DJI from less expensive jute imports. From a content perspective, they used the rhetoric of fairness, compassion towards workers and national interest. Each of these rhetorical foci was infused with the rhetoric of urgency. From an overall narrative perspective this process-based rhetoric attempted to create a call to action to restrict lowpriced, jute-based imports.

The types of content-based, rhetorical strategies of jute industry proponents have been previously identified in the model of discursive strategies of Vaara, et al (2006). As noted above, this model developed categories for rhetorical strategies of legitimation: normalization, authorization, rationalization, moralization and narrativization. While their model was developed in a different temporal, industrial and national context, it offers a framework applicable for understanding the key elements of rhetorical strategies of the Dundee Jute producers of the inter-war period. The table below illustrates the application of this model to the empirical context of this research, however the additional elements of urgency and avoidance will be examined later in the discussion.

Table 1: Application of Vaara, et al's (2006) Model of Discursive Strategies to the rhetorical strategies of DJI proponents during the 1938 legislative debates on UK trade policy:

\begin{tabular}{|l|l|}
\hline Rhetorical Themes from the Jute Debate & \multicolumn{1}{|c|}{ Vaara, et al. (2006) } \\
\hline Appeal to Fairness & moralization, rationalization \\
\hline Appeal to Compassion & moralization \\
\hline Appeal to National Interest & rationalization, moralization \\
\hline Appeal to Urgency & rationalization \\
\hline
\end{tabular}

In the Vaara, et al. (2006) model of discursive strategies, rationalization is defined as the process of “... legitimation by reference to the utility or function of specific actions or practices"(p. 800). The authors note that this particular form of rationalization highlights the financial and economic advantages of corporate restructuring. In the findings of the analysis of the jute debate, it is not surprising there is a close link between the rationalization and moralization categories, as Vaara, et al. (2006) state, “... all rationalizations, were based on specific moral and ideological grounds [in fact $]$... [r] ationalization always has a moral basis, although not always an explicit one ...'(p.801).

Yet there are further similarities in the legitimating rhetorical strategies used across both temporal/empirical contexts. The rhetorical strategy of aligning Jute industry proponents' interests with Britain's national interest was frequently employed, as identified above. Evocations of national interest in the industrial restructuring debates examined by Vaara, et al (2006) were used as a moralising rhetorical strategy. "More specifically, when journalists wanted to question the legitimacy of the merger or global industrial restructuring more generally, they often reverted to nationalistic (emphasizing the national interests as the key value) or humanistic (prioritizing the interests of the employees) discourses" (p. 801). These moralization and rationalization strategies, in the Finnish-Swedish context were, in the media, used as de-legitimating devices: rhetoric that sought to question the validity of industrial restructuring. In the UK jute debate, opponents of the 
free-trade oriented status quo used these strategies. Therefore in both contexts there were strategies of de-legitimation towards neo-liberal ideology and practice.

While these four primary rhetorical strategies have been identified, and articulated above, as separate rhetorical strategies, they were brought together and intertwined in the proponents' discursive argumentation. For example, there was significant overlap in the rhetoric of appeals to fairness and appeals to compassion towards workers. The foundation of the appeal to fairness was based on Dundee's inability to compete with cheaper imports. These imports were less expensive largely due to the fact that the cost of labour in India was significantly less. It was argued that this basic unfairness not only threatened jute producers, but by extension the workers, their livelihoods, their families and their communities.

Likewise, there were strong connections drawn between the overall financial health of the industry, and the health of the national economy. At times during the debate the issues of employment and national economic strength were used in tandem. Finally, the appeal to urgency was used to frame the entire discourse for Government action. A Government that failed to act quickly would abide unfairness, lack compassion and weaken the nation.

While it can be argued that the rhetorical strategy of urgency belongs to Vaara's category of rationalization because the argument is framed such that swift action would result in favourable outcomes and therefore is an argument, which appeals to rational action, this final rhetorical category can be viewed differently from the others. The first three provide the content of the overall argumentation, or the narrativization and while a sense of urgency does shape the narrative it can be viewed as process-focused, rather than content-focused. Within the context of the Vaara, et al (2006) model this is a more indirect method of addressing the issue of timing; however, the broader rhetorical literature does recognise the existence and importance of 'kairos' or an appeal to timing (Suddaby and Greenwood: 2005) as a viable rhetorical legitimating device.

\subsection{Avoiding rather than shifting Institutional Logics:}

Collectively, these four rhetorical appeals are intended to pass legislation that would allow Parliament to articulate to the Government that they should support British industries in general, and the DJI, in particular, by maintaining existing import tariff barriers and introducing further trade protections against less expensive imports which compete with domestic industries.

Previous rhetorical literature assumes that these discursive contests are intended to introduce profound institutional change by shifting dominant logics. (see Suddaby and Greenwood, 2005). However, what becomes clear in the analysis of the rhetorical strategies of industry supporters within parliament is that they attempted to separate Government policy from its institutional logic moorings. Government policy on tariffs had a clear free-trade orientation that was based on an underlying, dominant pro-liberal institutional logic. Rather than attempting to shift the dominant logic of free trade to one of protectionism, they focused their rhetoric on showing how the current policies were unfair and possibly anti-competitive. While the success of such rhetoric would mean a more protectionist, economic policy in practice, it was presented as if it could still be reconciled with, and indeed supported by, the institutional logic of free trade. In fact, when proponents of a proudly protectionist and anti-free trade amendment, that sought a complete ban on all imports produced in nations with wages and working standards lower than the UK, was introduced 
proponents of the original legislation spoke in opposition to this strong and direct challenge to the dominant free-trade institutional logic. Likewise, the rhetorical strategy of workers' welfare was employed not from an anti-free trade perspective, thus attempting to directly challenge the dominant pro-free trade logic, but rather, it was an attempt to highlight the Government's role of protecting and ensuring the welfare of society.

Finally, the rhetorical strategy of national interest was the closest that jute industry supporters came rhetorically to directly opposing or attempting to displacing the dominant, free trade institutional logic. However, rather than an attempt to usurp the dominate logic of free-trade with an insurgent logic of protectionism, they attempted to use another dominate logic of National Interest to advocate for their change in Government trade policy.

Prior research has focused on the role of rhetoric in legitimating profound institutional change (replacing dominant institutional logics in favour of new insurgent logics) (Suddaby and Greenwood: 2005); however, it should be noted that in this context proponents of change were more concerned about altering policy rather than shifting dominant logics. In fact, the dominant logics of free trade were never strongly or directly confronted by industry proponents. As noted above, the most direct challenge to the dominant pro-free trade logic was their use of another dominant logic, that of the national interest, and not the invocation of an alternative, insurgent, proprotectionist logic.

This case provides an example of rhetorical strategies that challenge policy, while avoiding a direct or explicit challenge to dominant institutional logics. In fact, the rhetoric seeks to set-aside a more fundamental debate on the appropriateness of current dominant logics to avoid resistance to their policy objectives even when, under close examination, their policy objectives are contradictory to dominant institutional logics. Overall, the rhetorical strategies employed by industry proponents were strengthened by, not a challenge to, the dominant institutional logics of the time.

\section{Conclusion}

This study focused on analysing rhetorical strategies employed by advocates of the DJI during the 1938 House of Parliament 'Importations from Overseas' debate in the United Kingdom. Proponents of the protection of the DJI sought to legitimise the preservation and imposition of import tariffs to counter growing international competition from foreign goods within their domestic market. It explored the relevance of Vaara et al's (2006) model for linguistic-based legitimation strategies to these findings. Clearly, the rhetoric applied by the jute industry was not able to persuade the Government to implement trade policies that would help protect the domestic industry from cheaper foreign imports. Although this study did not analyse the reasons for its failure, a possible explanation could be contextual in nature: the reduced political significance of the DJI to the national government (Cox 2013: 172-173).

This study makes the following contributions. First, while Vaara et al (2006) analysed the discursive strategies present in media accounts of a contemporary industrial merger, this study focuses on rhetorical strategies deployed in the realm of an historical public policy debate with the aim of influencing government to pursue a favourable trade policy to a particular industry. Importantly, the rhetoric was used to challenge policy, but not the underlying dominant logics. Second, existing literature on the DJI has focused on the government-industry relationship during the post-war period (1950s to 1960s) (Masrani and McKiernan 2011; Morelli, Tomlinson and 
Wright 2012) while this study provides further insight into this relationship, as it existed during the inter-war period. Third, this study develops the literature on 'language as a source of legitimacy' by shifting the focus of rhetorical studies away from individual firms to a declining industry and to Government debate. Finally, the study broadens the categorisations of rhetorical strategies and attempts to map these onto previous studies.

While this research focuses solely on the content of rhetorical strategies, an interesting focus for future research would be the process of rhetorical creation. For example, how were these strategies chosen? Were they deliberately chosen, random or emergent? Were the actors in the DJI unanimous in their agreement as to the rhetorical strategies that should be used? What was the role of individual personalities in shaping the industry's rhetorical approach? Further, a broader contextual study surrounding the UK's approach to free trade, that involved an analysis of the competitive position of the UK industries that had actual and potential success at the time, will enable the position of the DJI to be compared more fully and allow for a better reasoning on the failure of these particular rhetorical strategies. Finally, a study that examined the juxtaposition of an instance of rhetorical failure with an instance of rhetorical success, would allow for a greater understanding as to what makes a rhetorical appeal effective. Such a study could combine an examination of the process, content and context of rhetoric creation and deployment across empirical settings.

In the history of the DJI, decline continued from these inter war years until the last bale of jute was delivered and processed in Dundee in the late 1990s. The city's jute museum is the last vestige of a once proud and productive sector. 


\section{References}

Ashforth, B. E. \& Gibbs, B. W. (1990). The Double-Edge of Organizational Legitimation. Organization Science, 1, 177-194.

Cox, A. (2013). Empire, Industry and Class: The Imperial Nexus of jute, 1840-1940. Routledge.

DiMaggio \& Powell (1983). The iron cage revisited: Institutional isomorphism and collective rationality in organizational fields. American Sociological Review, 48, 147-160.

Dowling, J. \& Pfeffer, J. (1975). Organizational Legitimacy: Social values and Organizational Behaviour. Pacific Social Review.

Erkama, N. \& Vaara, E. (2010). Struggles Over Legitimacy in Global Organizational Restructuring: A Rhetorical Perspective on Legitimation Strategies and Dynamics in a Shutdown Case. Organization Studies, 31, 813-938.

Fairclough, N. (2007). Discourse in contemporary social change. Fairclough, N., Cortese, G. \& Ardizzone, P. (eds.). Peter Lang.

Fairclough, N. L. (2003). Analysing Discourse: Textual Analysis for Social Research. Routledge.

Freedman, A. \& Medway, P. (1994). Genre and the New Rhetoric, Bristol, PA, Taylor and Francis.

Gauldie, E. (1969) “The Dundee Textile Industry 1790-1885”, Constable.

Golant, B, Sillince, JAA. (2007). The constitution of organizational legitimacy: a narrative perspective. Organization Studies 2007, 28(8), 1149-1168.

Gupta, B. (2005) "Why did Collusion Fail? The Indian Jute Industry in the Inter-War Years", Business History, 47 (4), 532-552

Hansard (1938) Importations from Overseas. Vol. 331 cols. 239-305

Heracleous, L. \& Hendry, J. (2000). A structurational view of organizational discourses. Human Relations 53, 1251-1286.

Lenman, B. Lythe, C. and Gauldie, E. (1969) "Dundee and Its Textile Industry 1850-1914", Abertay Historical Society

Masrani, S. and P. McKiernan (2011). 'Accounting as a legitimising device in voluntary price agreements: the case of the Dundee jute industry, 1945-1960', Critical Perspectives on Accounting, 22 (4): 415-433

Meyer, J. W. \& Rowan, B. (1991). Institutionalized organizations: Formal structure as myth and ceremony. In: Powell, W. W., and P. J. DiMaggio (ed.) The new institutionalism in organizational analysis. Chicago, IL: University of Chicago Press.

Meyer, J. W. \& Scott, W. R. (1983). Centralization and the legitimacy problems of the local government. In: MEYER, J. W., AND W. R. SCOTT (ed.) Organizational Environments: Ritual and Rationality. Beverly Hills, CA: Sage. 
Morelli, C.J., Tomlinson, J., and Wright, V. (2012) The managing of competition: government and industry relationships in the jute industry 1957-63. Business History, 54 (5). pp. 765-782

Morelli, C.J, \& Tomlinson, J (2008), 'Women and Work after the Second World War: A Case Study of the Jute industry, circa 1945-1954' Twentieth Century British History, vol 19, no. 1, pp. 61-82.

Pfeffer, J. (1981). Power in Organizations, Harper Collins.

Phillips, N. \& Hardy, C. (2002). Discourse analysis. Investigating processes of social construction. Qualitative research methods series 50. Thousand Oaks, CA: Sage.

Phillips N, Lawrence TB, Hardy C. (2004). Discourse and institutions, Academy of Management Review, 29, 635-652.

Stewart, G. (1998) "Jute and Empire: The Calcutta Jute-Wallahs and the Landscapes of Empire", Manchester University Press,

Suddaby, R. \& Greenwood, R. (2005). Rhetorical Strategies of Legitimacy. Administrative Science Quarterly, 50, 32.

Vaara, E. \& Tienari, J. (2008). A discursive perspective on legitimation strategies in MNCs. Academy of Management Review, 33, 985-993.

Vaara, E., Tienari, J. \& Laurila, J. (2006). Pulp and Paper Fiction: On the Discursive Legitimation of Global Industrial Restructuring. Organization Studies, 27, 789-810.

Van Leeuwen, T. (2007). Legitimation in discourse and communication. Discourse \& Communication, 1, 91-112.

Wodak, R, de Cillia, R., Reisigl, M. \& Liebhart, K. (1999). The Discursive Construction of National Identity. Edinburgh: Edinburgh University Press.

Wodak, R., \& Meyer, M. (2002). Methods of critical discourse analysis., London, SAGE Publications.

Woodhouse, T. and Brand, A. (1934) “A Century’s Progress of Jute Manufacture”, David Winter, Dundee. 